\title{
Bullying, Victimization and Fighting in Secondary School: Gender-Based Differences
}

\author{
Varsha Saini $^{1^{*}}$ and Shanti Balda ${ }^{2}$ \\ ${ }^{1}$ Education Department, Haryana, India \\ ${ }^{2}$ Department of Human Development and Family Studies, I.C. Collage of Home Science, \\ CCS HAU Hisar - 125004, India \\ *Corresponding author:
}

\section{A B S T R A C T}

The present study was undertaken on 1070 children (571 boys and 499 girls) of secondary and senior secondary schools of Hisar district of Haryana state. The study was conducted

\section{Keywords}

Bullying,

victimization, fighting, boys, girls

Article Info

Accepted:

15 May 2019

Available Online:

10 June 2019 with all children enrolled in classes $6^{\text {th }}$ to $10^{\text {th }}$ from six selected schools (three schools from urban area and three schools from rural area i.e. Ladwa). This exploratory and crosssectional study aimed to identify the extent of bullying, victimization and fighting behaviour in a group of children and analyze the data regarding the gender of those involved in bullying, victimization and fighting behaviour. Illinois Bully Scale for children developed and standardized by Espelage and Holt (2001) was used to assess the bullying, victimization and fighting behaviour among school children. Children were personally interviewed about their bullying, victimization and fighting behaviour. Chi- square test was used to determine if there were statistically significant association between boys and girls. The results of the study highlighted that there was significant association between bullying, victimization, fighting behaviour and sex of children. Majority of the children both boys and girls were engaged in mild level of bullying, victimization and fighting behaviour. Percentages of boys were greater in moderate and severe bullying, victimization and fighting behaviour as compared to girls

\section{Introduction}

Bullying and victimization among school children are the significant public health problem in present scenario. Olweus and Limber (2010) defines bullying as "intentional, repeated, negative (unpleasant or hurtful) behaviour by one or more persons directed against a person who has difficulty defending himself or herself." This definition may apply to such aggressive behaviour caused by a person or group with manifest more power on a person or group with less power and this power particularly may be due to physical size, psychological/social power, or other factors Ferguson et al., (2007).

Victimization refers to the deliberately pain or injury to a person through physical or interpersonal means (Audrey et al., 2008). Victimization is experienced by an individual and their inability to react adequately to these 
situations causes high individual stress (Swearer and Hymel, 2015). Victims are more likely to avoid school or drop out, while the risk increases significantly when there is lack of parental support and positive peer relations, especially if there are additional behavioral problems (Swearer et al., 2010). Researchers observed that Victims of bullying had poor mental and physical health, more symptoms of anxiety, depression; feeling sad, being loneliness; vomiting; sleep disturbance; nightmares; body ache; a headache; abdominal pain, and frequent illnesses. Hence, victims of bullying suffers many health problems such as physical and psychological (Busch, 2014).

Bullying comprises direct and indirect forms of aggression. In direct forms of bullying includes Physical and verbal aggression and in indirect forms of bullying behaviour includes relational aggression. Any type of physical assault, such as hitting, pushing, kicking, choking, and forcefully taking something from the victim includes in physical bullying (Hinduja and Patchin, 2010). On the other hand verbal harassment or intimidation in the form of name-calling, threatening, taunting, malicious teasing, and psychological intimidation using words to harm victims includes in verbal bullying includes.

Relational aggression mainly includes social exclusion of victims through the manipulation of social relationships by bullies. Other forms of relational bullying are gossiping, slandering, sabotage, and convincing peers to exclude victims. Relational bullying is more common among girls and can lead to feelings of rejection at a critical time in social development (Smokowski and Kopasz, 2005). Research reveals that boys are generally victims of physical victimization, while girls are often victims of indirect victimization, like social exclusion (Swearer et al., 2010).
Bullying most often occurs in areas with little adult supervision, such as playgrounds and school hallways. Reactive aggression predicted higher future levels of peer victimization among boys relational aggression predicted increases in relational victimization among girls (Salmivalli and Helteenvuori, 2007; Ostrov, 2008).

It was also suggested by the findings that relational aggression expected decreases in relational victimization. Though, reactive relational aggression was found to expect increases in relational victimization (Blakely, 2014). Bullying not only obstructs adolescents' school performance, but can also supplies to psychosocial problems and alcohol and drug use (Bender and Losel, 2011).

Individuals with low self-control and deviant peer affiliations directly or indirectly affect victimization risks. Schreck et al., (2006) resulted that individuals with low self-control risked repeated victimization and were more likely to imbricate in delinquent activities and associate with deviant peers after being bullied. In another study also found a direct association between self-control deficit and victimization in females (Franklin et al., 2012).

\section{Materials and Methods}

The study was carried out in Hisar district of Haryana state. To draw the sample three secondary and senior secondary schools were selected randomly from Hisar city and similarly three secondary and senior secondary schools from rural area (village Ladwa) were selected at random.

The sample of the study consisted of 1070 children (500 from urban schools and 570 from rural schools) from the six selected schools. All the children participated in the study were registered in $6^{\text {th }}$ to $10^{\text {th }}$ classes. 


\section{Tools}

Illinois Bully Scale for children and standardized by Espelage and Holt (2001) was used to identify the bullying and victimization behaviour. This scale had 18 items divided in 3 subscales- bully subscale, victim subscale and fight subscale. But the researcher used two subscales i.e. bully subscale and victim subscale and fight sub scale had 5 items in the present study. Bully subscale had 9 items, victim subscale had 4 items. The students were asked to respond on five-point Likert-type scale with the assigned values for never (0), 1 or 2 times (1), 3 or 4 times (2), 5 or 6 times (3) and 7 or more times (4).

\section{Results and Discussion}

\section{Extent of bullying behavior among boys and girls}

To investigate the extent of bullying, total bullying score were computed and categorized into four levels- not victimized at all, mild, moderate and severe.

As shown in Table 1 that 57.27 per cent boys and 66.53 per cent girls were engaged in mild bullying behaviour. Table 1 further represents that 15.59 per cent boys and 23.85 of girls were not involved in bully perpetration. But 16.64 per cent boys and 7.41 per cent girls were involved in moderate bullying and 10.51 per cent boys and only 2.20 per cent girls were involved in severe bullying.

Chi square was computed to examine association between bullying behaviour among boys and girls. There was significant association between bullying behaviour of boys and girls, $\chi 2=59.09, \mathrm{p}<0.01$.

These finding are also consistent with previous studies conducted by Glew et al.,
(2005), Shin et al., (2016), Türkmen et al., (2013) reported that for boys, the likelihood of being involved in violent behaviours was found to be nearly 8.4 times higher as compared to girls. There was significant gender difference in bullying behaviour. Boys were more involved in bullying behaviours than girls either as bullies. Wet (2005) examined the prevalence of bullying during elementary school in a cross-sectional study and reported that bullies a large percentage of boys $(48.75 \%)$ were bullied as compared to girls $(6.15 \%)$.

\section{Extent of victimization among boys and} girls

To investigate the extent of victimization, total victimization score were computed and categorized into four levels- not victimized at all, mild, moderate and severe.

As shown in Table 2 that 23.85 per cent girls and 14.71 per cent boys had not been victimized at all. But 66.53 per cent girls and 47.29 per cent boys were mildly victimized. It was also found that 26.44 per cent boys belonged to moderate category of victimization and 11.56 per cent boys were severely victimized. Among girls, 7.41 per cent girls belonged to moderate category of victimization and 2.20 per cent girls belonged to severe category of victimization.

Chi square was computed to examine association between victimization and sex of children. There was significant association between victimization and sex of children, $\chi 2=10.88, p<0.01$. The results of present study are in line with finding of Khezri et al., (2013) conducted a study to explore the gender differences in the bullying and victimization. There were significant gender difference in bullying and victimization. Boys were more involved in bullying behaviours than girls either as bullies or bullying victims. 
Table.1 Extent of bullying behavior among boys and girls $(\mathrm{n}=1070)$

\begin{tabular}{|c|c|c|c|}
\hline Extent of bullying & Boys $(n=571)$ & Girls $(n=499)$ & $\chi^{2 \text {-value }}$ \\
\hline Not involved (0) & $89(15.59)$ & $119(23.85)$ & \multirow[t]{4}{*}{$59.09 * *$} \\
\hline Mild (1-9) & 327 (57.27) & $332(66.53)$ & \\
\hline Moderate (10-18) & $95(16.64)$ & $37(7.41)$ & \\
\hline Severe (19-36) & $60(10.51)$ & $11(2.20)$ & \\
\hline
\end{tabular}

Table.2 Extent of victimization among boys and girls $(\mathrm{n}=1070)$

\begin{tabular}{|c|c|c|c|}
\hline Extent of victimization & Boys $(n=571)$ & Girls $(n=499)$ & $\chi^{2}$-value \\
\hline Not involved (0) & $84(14.71)$ & $119(23.85)$ & \multirow[t]{4}{*}{$10.88^{* *}$} \\
\hline Mild (1-4) & $270(47.29)$ & $332(66.53)$ & \\
\hline Moderate (5-8) & $151(26.44)$ & $37(7.41)$ & \\
\hline Severe $(9-16)$ & $66(11.56)$ & $11(2.20)$ & \\
\hline
\end{tabular}

Table.3 Extent of fighting in boys and girls $(\mathrm{n}=1070)$

\begin{tabular}{|l|c|c|c|}
\hline Extent of fighting & Boys (n=571) & Girls (n=499) & \multirow{2}{*}{ 2-value } \\
\hline Not involved (0) & $85(14.89)$ & $107(21.44)$ & \multirow{2}{*}{$49.98^{* *}$} \\
\hline Mild (1-5) & $318(55.69)$ & $326(65.33)$ & \\
\hline Moderate (6-11) & $115(20.14)$ & $58(11.62)$ & \\
\hline Severe (12-20) & $53(9.28)$ & $8(1.60)$ \\
\hline Note: Figures in parentheses indicate percentages, **significant at 1\% level of significance \\
\hline
\end{tabular}

\section{Extent of fighting among boys and girls}

Extent of fighting among boys and girls was also assessed on four levels. As shown in Table 3 that 14.89 per cent boys and 21.44 per cent girls were not involved in fighting. More than fifty per cent boys (55.69\%) and 65.33 per cent girls were involved in mild fighting. Result further revealed that 20.14 per cent boys were involved in moderate fighting as compared to girls (11.62\%). More boys $(9.28 \%)$ were involved in severe fighting than girls $(1.60 \%)$.

Chi square was computed to examine association between fighting and sex of children. There was significant association between fighting behaviour and sex of children, $\chi 2=49.98, p<.01$. Similar results were also observed in previous studies by Rudatsikira et al., (2007), Pickett et al., (2013), Swahn et al., (2013) and Hussin et al., (2014) that the prevalence of physical fighting was higher in boys than girls. They suggested that a gender difference may be due to larger societal tolerance of physical violence among males vs. Females.

Majority of boys and girls were involved in mild bullying, victimization and fighting behaviour.

Percentages of boys were greater in moderate and severe bullying, victimization and 
fighting behaviour as compared to girls. There was significant association between bullying, victimization and fighting behaviour of boys and girls.

\section{References}

Audrey L. B., Storch E.A and Geffken G.R (2008). "Peer Victimization in Children with Learning Disabilities". Child and Adolescent Social Work Journal. 25.1: 11-23.

Bender, D., and Losel, F. (2011). Bullying at school as a predictor of delinquency, violence and other anti-social behaviour in adulthood. Criminal Behaviour and Mental Health, 21, 99-106. doi:10.1002/cbm.799

Blakely-McClure, S. J. (2014). A genderbalanced approachto the study of peer victimization and aggression subtypes in early childhood. Development and Psychopathology, 26, 575-587. doi: 10.1017/S0954579414000248

Busch V, Loyen A, Lodder M, Schrijvers A. $\mathrm{J}$, Yperen TA and Leeuw JR (2014). The effects of adolescent healthrelated behavior on academic performance: A systematic review of the longitudinal evidence. Review of Educational Research. 84(2):245-274.

Ferguson CJ, San Miguel C, Kilburn JC (2007). The effectiveness of schoolbased anti-bullying programs: a metaanalytic review. Crim Justice Rev. 32(4):401-414.

Franklin, C. A., Bouffard, L.A., and Pratt, T. C. (2012). Sexual assault on the college campus: Fraternity affiliation, malepeer support, and low self-control. Criminal Justice and Behavior, 39(11), 14571480

Glew, G.M., Fan, M., Katon, W., Rivara, F.P., and Y Kernic, M.A. 2005. Bullying psychosocial adjustment, and academic performance in elementary school.
Archives of Pediatric Adolescent Medicine, 159:1026-1031.

Hinduja S and Patchin JW (2010). Bullying, cyberbullying, and suicide. Arc Suicide Res.14:206-221.

Hussin S.F., Abd Aziz N.S., Hasim H., Sahril N (2014). Prevalence and factors associated with physical fighting among Malaysian adolescents. Asia Pac. J. Public Health. 26:108s-115s. doi: 10.1177/1010539514542423.

Khezri. H., Ebrahimi Ghavam., Mofidi.S and Delavar. F.A. 2013. A bullying and victimization: Prevalence and gender differences in a sample of Iranian middle school students. Journal of educational and management studies, 3: 224-229.

Olweus D and Limber SP (2010). Bullying in school: evaluation and dissemination of the Olweus Bullying Prevention Program. Am $J$ Orthopsychiatry. 80(1):124-34.

Ostrov, J. M. (2008). Forms of aggression and peer victimization during early childhood: A short-term longitudinal study. Journal of Abnormal Child Psychology. 36, 311-322. doi:10.1007/s10802-007-9179-3

Pickett W., Molcho M., Elgar F.J., Brooks F., Looze M., Rathmann K., Gabhainn S., Sigmundova D and Matos M.G., (2013). Trends and socioeconomic correlates of adolescent physical fighting in 30 countries. Pediatrics. 131:e18-e26. doi: 10.1542/peds.20121614.

Rudatsikira E., Siziya S., Kazembe L.N., Muula A.S (2007). Prevalence and associated factors of physical fighting among school-going adolescents in Namibia. Ann. Gen. Psychiatry. 6:18. doi: 10.1186/1744-859X-6-18.

Salmivalli, C., and Helteenvuori, T. (2007). Reactive, but not proactive aggression predicts victimization among boys. 
Aggressive Behavior, 33, 198-206. doi:10.1002/ab.20210

Schreck, C. J., Stewart, E. A., and Fisher, B. S. (2006). Self-Control, victimization, and their influence on delinquency and delinquent friends: A longitudinal analysis using panel data. Journal of Quantitative Criminology, 22, 319340.doi:10.1007/s10940-006-9014-y

Shin. H.H., Braithwaite. V and Ahmed. E. 2016. From traditional face- to- face bullying to cyber bullying: Who crosses over? https://openresearch repository. anu.edu.au/bitstream/ 1885/108952/ 2/01_Shin_From_Traditional_2016.pdf.

Smokowski PR and Kopasz KH (2005). Bullying in school: An overview of types, effects, family characteristics, and intervention strategies. Child Sch. 37(2):101-110.

Swahn M.H., Gressard L., Palmier J.B., Yao $H$ and Haberlen M (2013). The prevalence of very frequent physical fighting among boys and girls in 27 countries and cities: Regional and gender differences. J. Environ. Public Health. 2013; 2013: 215126. doi: $10.1155 / 2013 / 215126$.

Swearer S.M., Espelage D.L., Vaillancourt T and Hymel S (2010). "What Can Be Done about School Bullying? Linking Research to Educational Practice". Educational Researcher 39.1 (2010): 38-47.

Swearer, S. M., and Hymel, S. (2015). Understanding the psychology of bullying: Moving toward a socialecological diathesis-stress model. American Psychologist. 70(4), 344.

Turkmen. D.N., Dokgoz. M. H, Adgoz. S.S., Eren. B.N., Vural. E.H. and Polat. H.O. 2013. Prevalence of bullying behavior, its victims, types and places of bullying among 14-17 year old students in Bursa, Turkey. Maedica Buchar, 8(2): 143152.

Wet, De 2005. The nature and extent of bullying in free state secondary schools. South African Journal of Education, 25(2): 82-88.

\section{How to cite this article:}

Varsha Saini and Shanti Balda. 2019. Bullying, Victimization and Fighting in Secondary School: Gender-Based Differences. Int.J.Curr.Microbiol.App.Sci. 8(06): 1759-1764. doi: https://doi.org/10.20546/ijcmas.2019.806.210 